\title{
Development and Physicochemical Quality Assessment of Whey- Based Pineapple (Ananas comosus) Beverage
}

\author{
M.A.L.S.S. Munasinghe and H.N.N. Dilrukshi*
}

\begin{abstract}
The present investigation was aimed to develop a value added whey based pineapple beverage with acceptable sensory and nutritional characteristics along with its storage stability. The beverage samples were prepared using five different proportions $(0 \%, 15 \%, 25 \%, 35 \%$ and $45 \%)$ of pineapple juice in cheese whey. Amount of sugar was fixed at $5 \mathrm{~g}$ per $100 \mathrm{ml}$ of prepared beverage. The best formulation was selected through sensory evaluation and the physicochemical parameters of prepared beverages were determined at $7 \pm 1^{\circ} \mathrm{C}$ within 28 days of storage period. Whey beverage with $35 \%$ pineapple juice has scored the highest mean value (118.05) for overall acceptability in sensory evaluation. The storage studies were observed that total sugar content had a non-significant effect during storage period $(p>0.05)$. Based on the results of sensory analysis and storage studies, it can be concluded that a whey beverage combination with ripe pineapple juice can be prepared successfully by using the tested levels of, T3 $(35 \%$ pineapple juice $+65 \%$ whey $)$
\end{abstract}

Department of Livestock and Avian Sciences, Faculty of Livestock Fisheries and Nutrition, Wayamba University of Sri Lanka, Makandura, Gonawila, NWP, Sri Lanka.

*hnndilrukshi@gmail.com

http://orcid.org/0000-0001-9829-5940

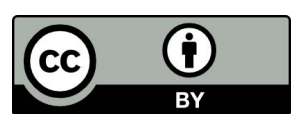

This article is published under the Creative Commons Attribution License (CC 4.0), which permits unrestricted use, distribution, and reproduction in any medium, provided the original work is properly cited. and T4 $(45 \%$ pineapple juice $+55 \%$ whey) as compared to other proportions used.

Keywords: Pineapple, Physicochemical parameters, Sensory properties, Storage, Whey

\section{INTRODUCTION}

With the development of world dairy processing industry number of nutritious byproducts which can be achieved a very good success on the market have been produced. Whey is one of such by-products obtained during coagulation of milk from cheese and paneer industry (Chavan et al., 2015). Whey contains about $85-90 \%$ of the total milk volume used for the preparation of cheese, and $55 \%$ of the milk nutrients retains in whey. The composition of liquid whey comprises lactose $(05 \%)$, water (93\%), proteins $(0.85 \%)$, minerals $(0.53 \%)$ and fat $(0.36 \%)$. Whey protein is present in small quantities but they have a high biological value (104), protein efficiency ratio (3.6) and net protein utilization (95) superior to other proteins such as egg, soy and caseins of milk (Smithers, 2008). Whey protein constitutes $\alpha$-lactalbumin, $\beta$ lactoglobulin, serum albumin, caseinomacropeptides, immune-globulins, lactoferrin, and lysozyme which have lots of health benefits, such as increased immunity and anticancer properties (Chavan et al., 2015). 
Based on the nutritional value of whey, number of different uses have been reviewed (Smithers, 2008). Over the years various attempts have been taken to transform whey liquid in the form of food based products such as beverages, spreads, sauces, dry soups, cookies and other bakery products. Dried whey is a very suitable 'bulking' food ingredient due to its bland taste compatible with many food processing applications (Jelen, 2011). Among these, one of the most attractive possibilities, of whey utilization is producing different kind of beverages (Djurić et al., 2004). The whey beverage processing has a long history and it was believed that producing whey drinks began in 1970-ies (Jeli et al., 2008) and one of the success oldest whey beverages is Rivella from Switzerland (Jelen, 2011). Recently commercial interest in whey beverages has increased among modern consumers in several European countries, because besides being delicious whey beverages are highly nutritious.

The most typical approach for development of whey beverages is, combining of whey with ripe fruit juices which are heavily compatible with the flavor characteristics of whey (Jelen, 2011). Several researchers have studied about beverages consisting of whey and fruit components such as orange, pear, peach, apple, mango, banana, pineapple and grapes (Djurić et al., 2004, Chavan et al., 2015, Dhamsaniya and Varshney, 2013 , Baljeeth et al., 2013; Bhat, 2014). Also there have been investigations on sensory characteristics, shelf life, microbiological quality of prepared whey based beverages (Vojnovic et al., 1993 and Sakhale et al., 2012).

Citrus fruits and other tropical fruits are the most frequently suggested for combination with whey drinks, because they have proved to be very efficient in reducing the undesirable odor and saltysour flavor of fresh whey (Djurić et al., 2004). Pineapple is one of the popular tropical fruits in Sri Lanka and it is commonly available in the market (Selvarajah et al., 1998). Pineapple is a rich source of vitamin $\mathrm{A}, \mathrm{B}$ and $\mathrm{C}$ and several minerals such as calcium, phosphorus and iron (Hossain and Rahman, 2011). The micronutrients containing in pineapple reduce the risk of occurring different types of cancer, cardiovascular and neurological diseases (Collins and Harrington, 2002).

However a very few studies have been taken to develop whey based beverages within Sri Lanka (Senarathne et al., 2009). It indicates that processing whey to beverages is not that much popular within country. Consumers may not be familiar with these types of beverages due to lack of any serious product development effort. The aim of present study was to develop a whey-based beverage which was obtained from cheddar cheese processing, combination with ripe pineapple juice and along with its storage study.

\section{MATERIALS AND METHODS}

Ripe pineapple was purchased by the local 
market in Gampaha, Sri Lanka. Sugar $\left(\mathrm{C}_{12} \mathrm{H}_{22} \mathrm{O}_{11}\right)$, Salt $(\mathrm{NaCl})$, food graded Sodium Metabisulphite $\left(\mathrm{Na}_{2} \mathrm{~S}_{2} \mathrm{O}_{5}\right)$ and citric acid $\left(\mathrm{C}_{6} \mathrm{H}_{8} \mathrm{O}_{7}\right)$ were purchased from JL Morison Son and Jones (Ceylon) PLC, Sri Lanka.

\section{Preparation of Whey}

Whey was obtained during producing of cheddar cheese in laboratory of Department of Livestock and Avian Sciences, Wayamba University of Sri Lanka. Then it was filtered through a muslin cloth and stored at $-20^{\circ} \mathrm{C}$. Frozen whey was thawed at $3^{\circ} \mathrm{C}$ before using.

\section{Preparation of Pineapple Juice}

The ripe pineapple was washed with running water and hand peeled. The eyes were removed. Then it was cut into small pieces using a knife. Small pieces were poured into a kitchen scale blender and crushed well. Then pineapple juice was filtered using a muslin cloth and it was used for beverage preparation (Baljeet et al., 2013).

\section{Treatment Details}

For the preparation of $100 \mathrm{ml}$ beverage following five different blends of pineapple juice and whey were used.

$\mathrm{T}_{0}=0 \%$ pineapple juice $+100 \%$ whey (Control)

$\mathrm{T}_{1}=15 \%$ pineapple juice $+85 \%$ whey

$\mathrm{T}_{2}=25 \%$ pineapple juice $+75 \%$ whey

$\mathrm{T}_{3}=35 \%$ pineapple juice $+65 \%$ whey
$\mathrm{T}_{4}=45 \%$ pineapple juice $+55 \%$ whey

\section{Preparation of Whey Based Pineapple Beverage (WBPB)}

The WBPB samples were prepared by adding corresponding pineapple juice: whey ratio together with sugar $(5 \mathrm{~g}$ sugar per $100 \mathrm{ml}$ of beverage) and $\mathrm{NaCl}$. Then each mixture was blended and boiled at $75^{\circ} \mathrm{C}$ for 10 minutes. The beverage samples were cooled to room temperature and the preservative (50 ppm sodium metabisulphite) was added according to the regulations made by the Minister of Health in terms of section 32 of the Food Act No.26 of 1980 in consultation with the Food Advisory Committee in Sri Lanka.

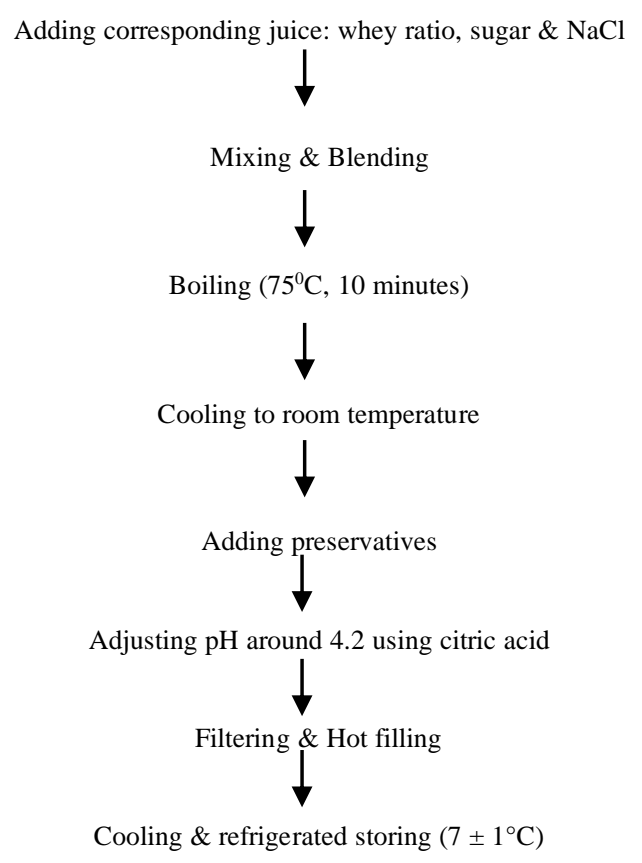

Figure1. Flow diagram for the preparation of whey-based pineapple beverage

The $\mathrm{pH}$ values of the WBPB samples were 
adjusted to 4.2 using citric acid. Then they were filtered and filled into pasteurized glass bottles and sealed. Finally, the prepared beverage samples were cooled to room temperature and stored under refrigerated conditions $\left(7 \pm 1^{\circ} \mathrm{C}\right)$.

\section{Physicochemical Analysis}

The whey sample, pineapple juice and beverage samples were analyzed for different physicochemical characteristics by applying standard methods. Total soluble solids were determined with Hand Held Refractometer (UK) and the values were expressed as ${ }^{0} \mathrm{Brix}$. Titratable acidity was calculated in terms of lactic acid for whey and citric acid for pineapple juice and beverage by titrating against $0.1 \mathrm{~N}$ $\mathrm{NaOH}$ according to AOAC method (AOAC, 2007). Protein content of whey sample was determined by Kjeldahl method (Kjeldahl apparatus- Buchi/ Switzerland, 2005) for nitrogen estimation, using factor of 6.38 for conversion of nitrogen into protein (Mariotti et al., 2008).

Fat content of whey sample was determined by Gerber centrifuge method (Kleyn et al., 2001). Digital pH meter (ST 3000- Ohaus Corporation -USA) was used for $\mathrm{pH}$ measurements. Specific minerals ( $\mathrm{Ca}, \mathrm{Mg}, \mathrm{Zn}, \mathrm{Cu}$, and $\mathrm{Fe}$ ) of whey sample were measured using Atomic Absorption Spectrophotometry (AAS- Thermo scientific - UK) as reported by Skoog et al. (2007). The reducing sugar content and total sugar content of pineapple juice and beverages were determined as described by Lane and Eynon (Lane and Eynon, 1934).
The ascorbic acid content of pineapple juice and beverages were determined according to a redox iodometric titration using starch as an indicator (University of Canterbury College of Science, 2017).

\section{Sensory Analysis}

Five different blends of beverage samples were exposed sensory analysis using 30 untrained panelists. The beverage samples were evaluated for appearance, color, texture, odor, taste and overall acceptance. The panelists were asked to record their observations on the sensory sheet based on Hedonic scale with five-point score values ranging from 5: "Like Extremely" to 1: "Dislike Extremely".

\section{Storage Studies}

Five treatments were stored at refrigerated temperature $\left(7 \pm 1^{\circ} \mathrm{C}\right)$ for 28 days because according to the previous studies whey beverages prepared from freshly added fruit pulps have been stored within 28 to 45 days (Bhat, 2014). The current study was conducted within 28 days based on the available facilities. For the analysis, juice samples were drawn at intervals of 4 days and evaluated for physico-chemical characteristics.

\section{Statistical Analysis}

The sensory data were analyzed statistically using SAS system under Wilcoxon rank sums and Kruskal - Wallis test. The storage data were analyzed using SPSS 16 software under factorial 
Completely Randomized Design at 95\% confidence level.

\section{RESULTS AND DISCUSSION}

Physicochemical Characteristics of Raw Materials (Whey Liquid and Pineapple Juice)

The sweet liquid cheddar cheese whey was assessed for total solids, $\mathrm{pH}$, acidity, crude protein, fat and specific mineral content ( $\mathrm{Ca}, \mathrm{Mg}, \mathrm{Fe}$ and $\mathrm{Zn}$ ) as shown in Table 1. According to the results, whey showed $6.52 \%$ of total solids, $5.94 \mathrm{pH}, 0.23 \%$ acidity (measured as percent lactic acid), $0.98 \%$ crude protein and $0.66 \%$ of fat. $\mathrm{Ca}$ $(334.42 \mathrm{mg} / \mathrm{L})$ was present in high concentrations in whey liquid among the tested minerals.

Table 1. Composition of whey liquid and pineapple juice

\begin{tabular}{lll}
\hline Parameter & Whey & Pineapple \\
\hline TSS $\left(\right.$ Brix $\left.^{0}\right)$ & 6.52 & 10.92 \\
$\mathrm{pH}$ & 5.94 & 3.63 \\
Acidity $(\%)$ & 0.2270 & 1.2243 \\
Crude protein (\%) & 0.98 & - \\
Fat (\%) & 0.66 & - \\
Mineral content & & \\
(mg/L) & 334.42 & - \\
$\mathrm{Ca}$ & 79.63 & - \\
$\mathrm{Mg}$ & 9.27 & - \\
$\mathrm{Fe}$ & 0.58 & - \\
$\mathrm{Zn}$ & - & 14.33 \\
Ascorbic acid & - & \\
content & & \\
$\quad$ (mg/100g of & & \\
Rample) & & 5.80 \\
Reducing sugars $(\%)$ & - & 12.13 \\
Total sugars (\%) & - & \\
\end{tabular}

The pineapple juice showed 10.92 $\left(\mathrm{Brix}^{0}\right)$ Total Soluble Solids (TSS), 1.22\% acidity (measured as percent citric acid) and $3.63 \mathrm{pH}$ which was lesser than $\mathrm{pH}$ of whey. The ascorbic acid content (14.33 $\mathrm{mg} / 100 \mathrm{~g}$ of sample), reducing sugar content $(5.80 \%)$ and total sugar content $(12.13 \%)$ of pineapple juice were in accordance with the earlier work of Baljeet et al. (2013). Different studies have reported that average ascorbic acid content for pineapple varies according to the variety. In addition to the varietal effect, the ascorbic acid content can be affected by additional factors, such as clone, climatology and geographical conditions and acidity (Lu et al., 2014).

\section{Effect of Different Treatment Levels on Sensory Characteristics of Whey Based Pineapple Beverage}

The five different blends of whey and pineapple juice were evaluated for sensory attributes namely appearance, color, texture, odor, taste and overall acceptance. It was observed from Table 2 that whey beverage with $35 \%$ pineapple juice $\left(\mathrm{T}_{3}\right)$ has scored the highest mean scores for taste (110.53), overall acceptance (118.05) and odor (112.13). The appearance, color and texture of beverage samples increased significantly when increasing the amount of pineapple ratio used. Therefore, it was observed that the whey beverage with $45 \%$ pineapple juice $\left(\mathrm{T}_{4}\right)$ has scored highest mean scores for appearance, color and texture of beverages.

The lowest mean scores for almost all sensory attributes were obtained by control sample $\left(\mathrm{T}_{0}\right)$ indicating that control has the 
lowest consumer acceptance. Also, according to the statistical analysis effect of five treatment levels on all sensory characteristics were significantly different $(p<0.05)$. The results are in agreement with findings of Shukla et al. (2013) and Bhavsagar et al. (2010) where the control sample has the lowest mean scores for all sensory attributes in sensory analysis of prepared pineapple flavored beverage from Channa whey while the highest mean scores were obtained by the sample which was having high proportion of pineapple juice. Finally, the present study sensory evaluation data indicated that whey-based beverage blending with 35 and 45 percent pineapple juice were found to be superior in terms of consumer preference.

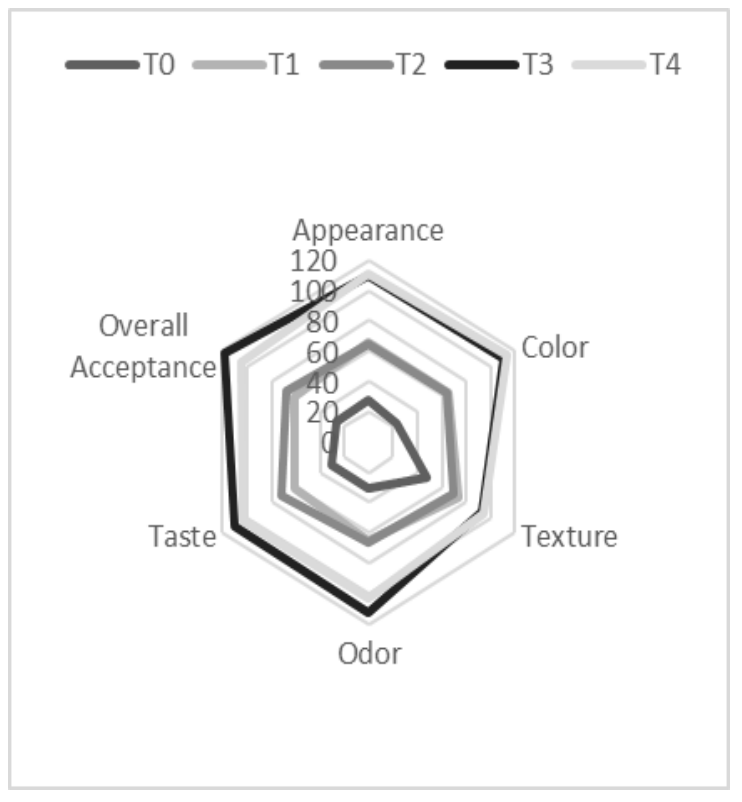

Figure 2. Changes in mean scores of sensory attributes among different treatments

Table 2: Changes in mean scores of sensory attributes among different treatments

\begin{tabular}{lllllll}
\hline Treatment & Appearance & Color & Texture & Odor & Taste & Overall Acceptance \\
\hline $\mathbf{T}_{\mathbf{0}}$ & 27.17 & 23.50 & 47.68 & 30.70 & 30.83 & 26.20 \\
$\mathbf{T}_{\mathbf{1}}$ & 65.95 & 65.73 & 73.20 & 65.28 & 61.200 & 60.40 \\
$\mathbf{T}_{\mathbf{2}}$ & 63.92 & 63.75 & 68.95 & 66.28 & 71.98 & 67.77 \\
$\mathbf{T}_{\mathbf{3}}$ & 110.02 & 110.65 & 92.92 & 112.13 & 110.53 & 118.05 \\
$\mathbf{T}_{\mathbf{4}}$ & 110.45 & 113.87 & 94.75 & 103.10 & 102.95 & 105.08 \\
\hline
\end{tabular}

Effect of Different Treatment Levels and Storage Period on Physicochemical Characteristics of Whey Based Pineapple Beverage

It was observed that the five different treatment levels have affected the TSS content of WBPB (Whey Based Pineapple Beverage) considerably. The TSS content of fresh WBPB samples of $\mathrm{T}_{0}$ (control), $\mathrm{T}_{1}, \mathrm{~T}_{2}, \mathrm{~T}_{3}$ and $\mathrm{T}_{4}$ were $11.87,12.47,12.57$,
12.60 and 12.67 Brix $^{0}$ (Table 3), respectively. It was indicated that the TSS content has increased when the volume of pineapple portion was increased. This relationship was statistically confirmed $(p<0.05)$. Table 3 showed that the storage period has significantly affected on the average TSS of the beverage samples indicating an increasing trend $(p<0.05)$. The highest mean TSS content was observed at the end of 28 days, which was 
recorded as 13.20 Brix $^{0}$. The reason for increasing TSS content may be solubilization of insoluble portion of beverage samples due to the presence of ascorbic acid and citric acid according to Sethi (1992). Baljeet et al. (2013) Dhamsaniya and Varshney (2013) and Yadav et al. (2010) were also obtained the similar results in case of preparing wheybased pineapple and bottle gourd beverage, ripe banana mixed whey beverage and banana herbal whey beverage.

The $\mathrm{pH}$ values of beverage samples decreased gradually with the five treatment levels (Table 3). This indicated that by increasing pineapple juice concentration, $\mathrm{pH}$ values decreased in prepared beverages significantly $(p<0.05)$. Storage period significantly affected on the average $\mathrm{pH}$ values of beverage samples $(\mathrm{p}<0.05)$. By increasing the storage period, the $\mathrm{pH}$ of all treatment decreased. The interaction effect of treatment levels and storage period on $\mathrm{pH}$ was also significant $(\mathrm{p}<0.05)$.

On the other hand, the titratable acidity increased slightly when increasing the proportion of pineapple juice in five beverage samples indicating that the differences were significant $(p<0.05)$. The effect of storage period on titratable acidity of beverage samples was found to be significant and the mean value of $0.98 \%$ acidity in freshly prepared beverages increased to $1.06 \%$ of mean acidity after 28 days of storage period. The interaction effect of treatment levels and the storage period on titratable acidity was also, significant $(\mathrm{p}<0.05)$.

The decrease in $\mathrm{pH}$ and increase in acidity of all five treatment levels during storage period were due to the conversion of lactose present in whey into lactic acid. $\mathrm{pH}$ and acidity of beverage samples in current study were in agreement with the findings of Yadav et al. (2010), where they observed that decreasing trend in $\mathrm{pH}$ as acidity level increases in whey based banana herbal beverage in which $\mathrm{pH}$ varied significantly from $5.47 \pm 0.02$ to $5.01 \pm 0.01$ after 20 days of storage at refrigerated temperature. Similarly, acidity has changed from 0.38 to 0.49 during the entire period explaining that the reason for $\mathrm{pH}$ and acidity fluctuation is due to the production of amino and organic acids from proteins and lactose during storage.

Production of different organic acids due to the reactions of ascorbic acids on proteins might be another reason for variations in acidity and $\mathrm{pH}$. Ascorbic acid, is a reducing carbohydrate and can react with amino acids, peptides, and proteins hence the ascorbic acid is readily oxidized (Frank et al., 2004). Similar results have also been recorded by Sakhale et al. (2012) when preparing whey-based mango RTS (Ready to Serve) beverage and Divya et al. (2014) when preparing whey-based guava beverage.

It can be observed that the reducing sugar content increased as the pineapple juice concentration was increased from $15 \%$ to $45 \%$ in the prepared WBPB (Table 
4). The statistical analysis indicated that there was a significant effect on reducing sugar content from different treatment levels $(p<0.05)$. The reducing sugar content of beverages increased during storage period and it was statistically significant $(\mathrm{p}<0.05)$. Also the interaction effect of treatment levels and storage period on reducing sugars was significant $(p<0.05)$. The reason for increasing reducing sugars during storage period might be due to the inversion or hydrolysis of sucrose into glucose and fructose (Aruna et al., 1997). The fruit juice contains various non-reducing sugars which tend to change during storage due to various interconversion processes. Increasing of reducing sugars could be resulted due to hydrolysis of polysaccharides into simple sugars as reported by Singh and Mathur (1983). They had proposed that an increase in reducing sugar during storage may be due to gradual conversion of non-reducing sugar and acids into reducing sugars. Similar results were also obtained by Yadav et al. (2010), Divya et al. (2014) and Dhamsaniya and Varshney (2013).

The total sugar content of freshly prepared beverage samples of $\mathrm{T}_{0}$ (control), $\mathrm{T}_{1}, \mathrm{~T}_{2}, \mathrm{~T}_{3}$ and $\mathrm{T}_{4}$ were 9.09, 11.13, 11.18, $11.28,11.33(\%)$, respectively (Table 4$)$. The analysis of data reported that there was a significant effect on titratable acidity from different treatment levels $(p<0.05)$. The storage period did not significantly affect on the total sugar content of WBPB samples $(\mathrm{P}>0.05)$. The mean total sugar value of $10.80 \%$ for freshly prepared beverages remained same almost after 28 days of storage period. On the other hand, Barwal et al. (2005) have observed a decrease in total sugar content during storage studies of prepared RTS whey beverage from bitter-gourd in which storage study period (180 days) was much higher.

The ascorbic acid content of beverages significantly increased by increasing the proportion of pineapple juice (Table 4). The result seems obvious because the pineapple fruit is considered as a good source of vitamin $\mathrm{C}$ which is determined as total ascorbic acid content (Lu et al., 2014). The storage period also had a significant effect on ascorbic acid content of WBPB samples $(p<0.05)$. The mean ascorbic acid value of five treatments has decreased drastically during 28 days of storing period from 4.01 to $0.96(\mathrm{mg} / 100 \mathrm{~g}$ of sample) as shown in Table 4 . This could be mainly due to the high sensitive nature of ascorbic acid towards the storing period (Uckiah et al., 2007) and the results were in agreement with also the findings reported by Baljeet et al. (2013) and Sakhale et al. (2012).

Based on the storage study results; TSS, pH and titratable acidity revealed desirable ranges throughout the 28 days for all beverage samples while the properties which increase the overall quality of the final WBPB sample such as ascorbic acid content and reducing sugar content have reached higher levels in $\mathrm{T} 4$ beverage sample after 28-days as compared to other proportions. 
Table 3: Effect of treatment levels (pineapple juice: whey) and storage period on TSS (Brix $\left.{ }^{0}\right), \mathrm{pH}$ and Acidity (\%) of whey-based pineapple beverage

\begin{tabular}{|c|c|c|c|c|c|c|c|c|c|c|c|c|c|c|c|c|c|}
\hline \multirow{2}{*}{$\begin{array}{l}\text { Storage } \\
\text { days }\end{array}$} & \multicolumn{6}{|c|}{ TSS $\left(\right.$ Brix $\left.^{0}\right)$} & \multicolumn{6}{|c|}{$\mathrm{pH}$} & \multicolumn{5}{|c|}{ Acidity (\%) } \\
\hline & $T_{0}$ & $T_{1}$ & $\mathbf{T}_{2}$ & $T_{3}$ & $T_{4}$ & $\begin{array}{l}\text { Mean } \\
\text { for B }\end{array}$ & $T_{0}$ & $\mathrm{~T}_{1}$ & $\mathbf{T}_{2}$ & $\mathbf{T}_{3}$ & $T_{4}$ & $\begin{array}{l}\text { Mean } \\
\text { for B }\end{array}$ & $\mathbf{T}_{0}$ & $\mathbf{T}_{1}$ & $\mathbf{T}_{2}$ & $\mathrm{~T}_{3} \quad \mathrm{~T}_{4}$ & $\begin{array}{l}\text { Mean } \\
\text { for B }\end{array}$ \\
\hline $\mathbf{0}$ & 11.87 & 12.47 & 12.57 & 12.60 & 12.67 & 12.43 & 4.26 & 4.23 & 4.23 & 4.21 & 4.17 & 4.22 & 0.46 & 0.97 & 1.03 & 1.201 .26 & 0.98 \\
\hline 4 & 12.07 & 12.67 & 12.73 & 12.63 & 12.80 & 12.58 & 4.17 & 4.15 & 4.12 & 4.10 & 4.03 & 4.12 & 0.47 & 0.97 & 1.05 & $\begin{array}{lll}1.20 & 1.27\end{array}$ & 0.99 \\
\hline 8 & 12.17 & 12.70 & 12.87 & 12.97 & 12.97 & 12.73 & 4.20 & 4.17 & 4.15 & 4.13 & 4.07 & 4.14 & 0.49 & 1.01 & 1.08 & 1.231 .28 & 1.02 \\
\hline 12 & 12.37 & 12.83 & 13.07 & 13.07 & 13.10 & 12.87 & 4.14 & 4.08 & 4.09 & 4.06 & 4.02 & 4.08 & 0.51 & 1.02 & 1.11 & 1.251 .31 & 1.04 \\
\hline 16 & 12.37 & 12.77 & 13.17 & 13.07 & 13.17 & 12.91 & 4.11 & 4.07 & 4.07 & 4.05 & 4.01 & 4.06 & 0.52 & 1.04 & 1.12 & $\begin{array}{lll}2 & 1.28 & 1.32\end{array}$ & 1.05 \\
\hline 20 & 12.47 & 12.87 & 13.13 & 13.30 & 13.23 & 13.00 & 4.07 & 4.03 & 4.01 & 3.99 & 3.96 & 4.01 & 0.52 & 1.06 & 1.13 & $\begin{array}{lll}3 & 1.30 & 1.33\end{array}$ & 1.07 \\
\hline 24 & 12.57 & 12.87 & 13.27 & 13.27 & 13.37 & 13.07 & 4.15 & 4.03 & 4.00 & 3.98 & 4.00 & 4.03 & 0.44 & 1.09 & 1.11 & $\begin{array}{llll}1 & 1.25 & 1.36\end{array}$ & 1.05 \\
\hline 28 & 12.67 & 13.13 & 13.37 & 13.37 & 13.47 & 13.20 & 4.13 & 4.01 & 3.99 & 3.98 & 3.97 & 4.01 & 0.48 & 1.10 & 1.13 & $\begin{array}{llll}3 & 1.25 & 1.36\end{array}$ & 1.06 \\
\hline $\begin{array}{c}\text { Mean for } \\
\text { A }\end{array}$ & 12.32 & 12.79 & 13.02 & 13.03 & 13.09 & & 4.15 & 4.10 & 4.08 & 4.06 & 4.03 & & 0.48 & 1.03 & 1.09 & $\begin{array}{lll}9 & 1.24 & 1.31\end{array}$ & \\
\hline
\end{tabular}

CD (Critical Difference) for TSS

Treatment $(A)=0.00$

Storage $(B)=0.00$

$(A * B)=0.00$

\section{$C D$ for $p H$}

Treatment $(A)=0.00$

Storage $(B)=0.00$

$(A * B)=0.00$
$C D$ for Acidity

Treatment $(A)=0.00$

Storage $(B)=0.00$

$(A * B)=0.00$ 
Table 4: Effect of treatment levels (pineapple juice: whey) and storage period on Reducing sugars, Total sugars and Ascorbic acid content of whey-based pineapple beverage

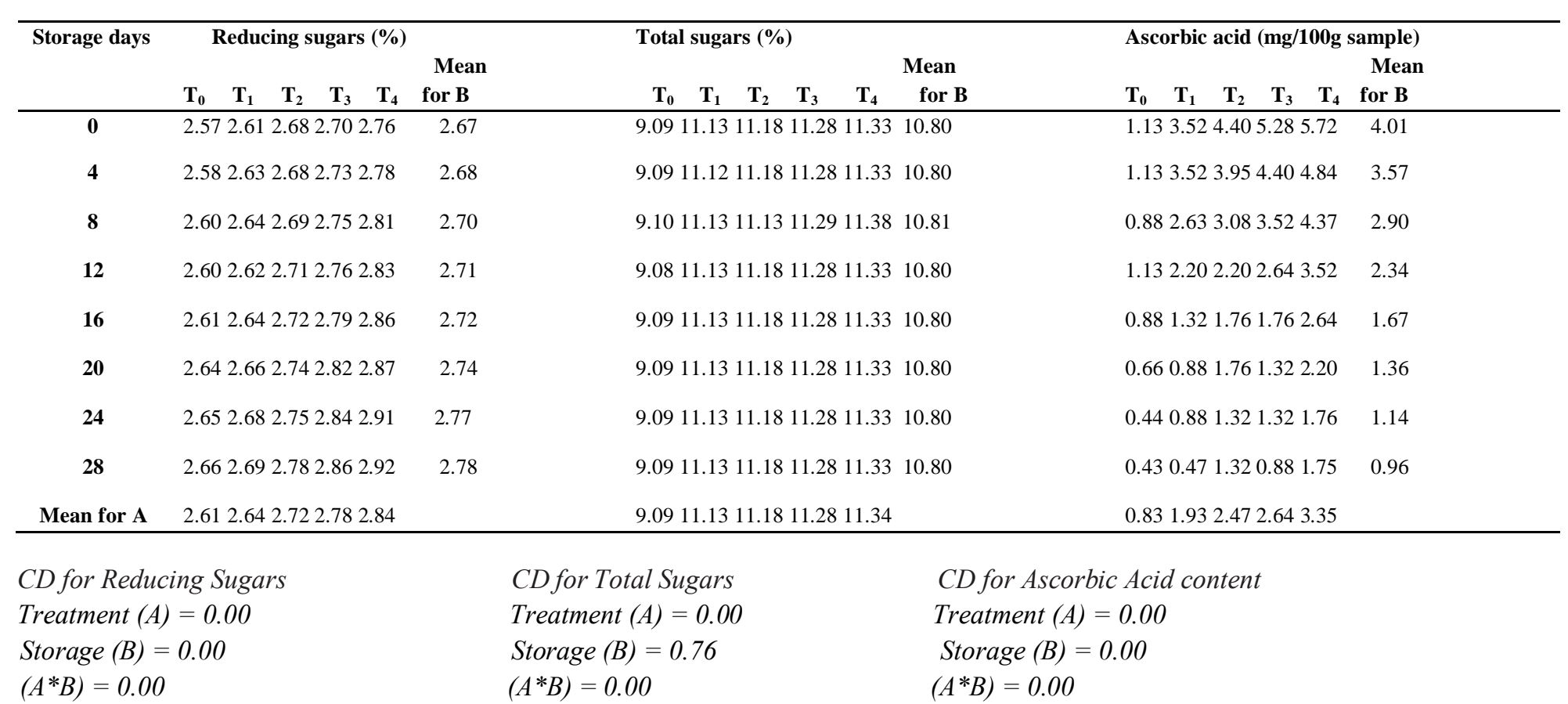


beverage sample after 28-days as compared to other proportions

\section{CONCLUSION}

From the results obtained based on the sensory analysis and storage studies, it can be concluded that whey beverage combination with ripe pineapple juice can be prepared successfully by using the tested levels of, T3 $335 \%$ pineapple juice + $65 \%$ whey) and $\mathrm{T}_{4}$ (45\% pineapple juice + $55 \%$ whey) as compared to other proportions. Also the product can be proved a nutritionally desirable beverage according to the composition of whey and pineapple juice. Whey based pineapple beverage significantly increases acidity; TSS and reducing sugar content and decreases $\mathrm{pH}$ and ascorbic acid in all five treatment levels with storage time.

\section{ACKNOWLEDGEMENT}

Authors acknowledge Mr. I.W.M.D. Nalaka Sandaruwan, Technical Officer, Department of Livestock and Avian Sciences, Wayamba University of Sri Lanka, for assisting the research.

\section{REFERENCES}

AOAC, (2007). Official methods of analysis of AOAC international $18^{\text {th }}$ edition, Gaithersburg, MD. USA. Available from: https://www.aoac.org (Accessed 17 January 2018).

Aruna, K., Vimla, V., Giridhar, N. and Rao, D.G. (1997). Studies on preparation and storage of nectar prepared from papaya (Carica papaya L.). Beverage Food World, 24: 29-32.

Baljeet, S.Y., Ritika, B.Y. and Sarita, R. (2013). Studies on development and storage of whey-based pineapple (Ananas comosus) and bottle gourd (Lagenaria siceraria) mixed herbal beverage. International Food Research Journal, 20(2): 607-612.

Barwal, V.S., Singh, T.K. and Alkesh. (2005). Studies on processing and development of ready-to-serve drink from bittergourd fruit. Journal of Food Science and Technology, 42(3): 217220.

Bhat, F. (2014). Development, quality evaluation and shelf life studies of whey guava beverage. International Journal of Current Engineering and Technology, 4(3).

Bhavsagar, M.S., Awaz, H.B. and Patange, U.L. (2010). Manufacture of pineapple flavoured beverage from chhana whey. Journal of Dairying Foods \& Home Sciences, 29(2): 110-113.

Chavan, R., Nalawade, T. and Kumar, A. (2015). Studies on the development of whey based mango beverage. Journal of Food and Dairy Technology, 3(2): 1-6.

Collins, A. R. and Harrington, A (2002). Antioxidants: not the only reason to eat fruit and vegetables. Phytochemistry Reviews, 1(2): 167-174.

Dhamsaniya, N.K. and Varshney, A. K. (2013). Development and evaluation of whey based RTS beverage from ripe banana juice. Journal of Food Processing and Technology, 4: 203.

Singh, D., Rongen, S.A. and Bhatt, A.F. 
(2014). Development, quality evaluation and shelf life studies of whey guava beverage. International Journal of Current Engineering and Technology, 4(3): 2171-2175.

Djurić, M. (2004). Development of wheybased beverages. In: European Food Research and Technology, 321-328.

Frank, A.A., Cluster, T.J., Arakaki, C. and Murphy, S.P. (2004). Vitamin C and flavonoids level of fruits and vegetables consumed in Hawaii. Journal of Food Composition and Analysis, 17: 1-35.

Hossain, M.A. and Rahman, S.M.M. (2011). Total phenolics, flavonoids and antioxidant activity of tropical fruit pineapple. FRIN, 44(3): 672-676.

Jelen, P. (2011). Whey processing. In: H. Roginski, P.F. Fox and J.W. Fuquay (Editors), Encyclopedia of Dairy Sciences. Academic Press, London, UK, 731-737.

Jeli, I., Božani, R. and Tratnik, L. (2008). Whey-based beverages- a new generation of diary products. Mljekarstvo, 58(3): 257-274.

Kleyn, D., Lynch D.Y., Barbano, D., Bloom, J. and Mitchell, M. (2001). Determination of Fat in Raw and Processed Milks by the Gerber Method: Journal of AOAC International, 84(5): 1499-508.

Lane, J. H. and Eynon, L. (1934). Determination of reducing sugars by Fehling's solution with methylene blue indicator. N. Rodger.

Lu, X.H., Sun D.Q., Wu, Q.S., Liu, S.H. and Sun, G.M. (2014). Physicochemical properties, antioxidant activity and mineral content of pineapple genotypes grown in China. Molecules, 19: 8518-8532.

Mariotti, F., Tomé, D. and Mirand, P.P. (2008). Converting nitrogen into protein - Beyond 6.25 and Jones' factors. Crit. Reviews Food Science and Nutrition, 48: 177-184.

Sakhale, B.K., Pawar, V.N. and Ranveer, R.C. (2012). Studies on the Development and storage of whey based RTS beverage from mango $c v$. Kesar. Journal of Food Processing Technology, 3: 148.

Selvarajah, S., Herath, H.M.W. and Bandara, D.C. (1998). Effect of Preharvest calcium treatment on postharvest quality of pineapple. Tropical Agricultural Research, 10: 214-224.

Sethi, V. (1992). Preparation and storage study of lime ginger cocktail at room and low temperature. Beverage Food World, 19: 51-52.

Senarathna, I.W.P., Bandara, R.M.A.S., Wickramanayaka, D., Udayathilaka, E.U. and Wijeratne, A.W. (2009). Development of a cultured milk beverage using chedder chees whey. Journal of Agricultural Sciences-Sri Lanka: 29-44.

Shukla, M., Jha, Y.K. and Admassu S. (2013). Development of probiotic beverage from whey and pineapple Juice. Journal of Food Process Technology, 4: 206.

Singh, K. and Mathur, P. B. (1983). Studies in the cold storage of cashew apple. Indian Journal of Horticulture, 40: 115-121.

Sirohi, D., Patel, S., Choudhary, P.L. and 
Sahu, C. (2005). Studies on preparation and storage of whey-based mango herbal pudina (Mentha arvensis) beverage. Journal of Food Science and Technology, 42(2): 157161.

Skoog, D.A., Holler, F.J. and Crouch S.R. (2007). Principles of Instrumental Analysis. Canada.

Smithers, G.W. (2008). Whey and whey proteins-from 'gutter-to-gold'. International Dairy Journal, 18: 695704.

Uckiah, A., Goburdhun, D. and Ruggoo, A. (2007). Vitamin C content during processing and storage of pineapple. Nutrition \& Food Science, 39(4): 398412.

University of Canterbury College of Science (2017). Determination of Vitamin C Concentration by Titration. University of Canterbury College of Science.

Vojnovic, V., Ritz, M. and Vahcic, N. (1993). Sensory evaluation of wheybased fruit beverages, Food/Nahrung, 37: 246-251.

Yadav, R.B., Yadav, B.S. and Kalia, N. (2010). Development and storage studies on whey based banana herbal (Mentha arvensis) beverage. American Journal of Food Technology, 5(2): 121-129. 